\title{
The Challenge of Archaeological Interpretation and Practice that Integrates between the Science of the Past and Local Knowledge ความท้าทายของการตีความและปฏิบัติการทางโบราณคดีที่บูรณา การระหว่างวิทยาศาสตร์ของอดีตกับภูมิปัญญาท้องถิ่น
}

\author{
Rasmi Shoocongdej \\ Department of Archaeology, \\ Faculty of Archaeology, \\ Silpakorn University
}

Correspondence: $\underline{\text { rasmi } @ \text { su.ac.th }}$

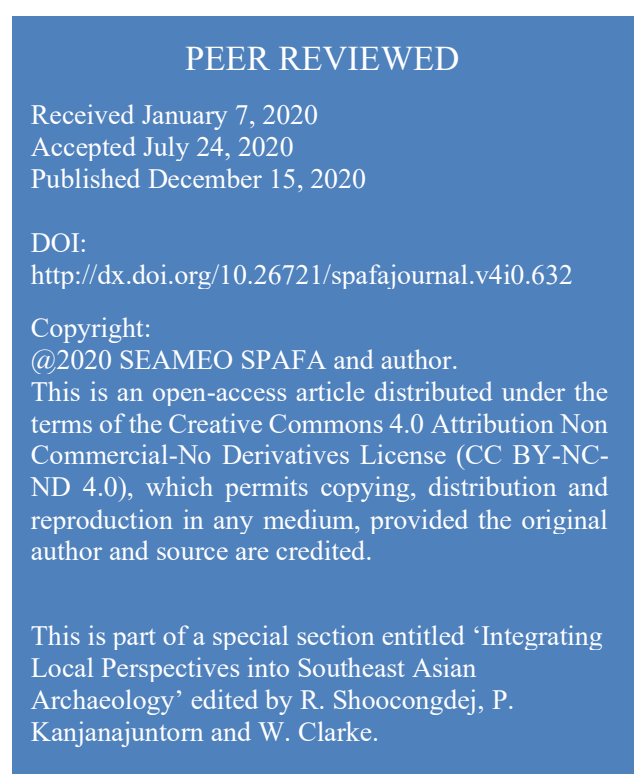

\begin{abstract}
Contemporary archaeologists can no longer focus only on scientific research, they must also work with different interest groups whose use of archaeology may have positive and negative consequences. The dichotomy of foreigner versus local has been prominent in the discourse of the post-modern era. Archaeologists seem to be aware of their ethical and political roles when archaeology is used for knowledge production, economic development, and other public policy goals at the local, national and international levels. Consequently, in recent years the ethical issues involved in working with multiple communities or multi-ethnic groups have become important concerns for archaeologists globally. In the case of Thailand, most archaeologists generally have not focused on these issues, although there are many minority ethnic groups there, especially near the borders with neighboring countries. The challenge now is to integrate professional theoretical and methodological practice with local wisdom from multiple communities even though these are forms of knowledge different from a "scientific" world view. This paper considers two major topics: (1) how archaeologists negotiate their ethical responsibilities in working with the multiple communities and, (2) how archaeologists can incorporate local knowledge into archaeological practice and interpretation, using an example from Highland Pang Mapha in Mae Hong Son province Northwestern Thailand.
\end{abstract}

นักโบราณคดีร่วมสมัยไม่สามารถเน้นเฉพาะการทำวิจัย พวกเขาต้องทำงานร่วมกับกลุ่มคนที่มีความ สนใจในงานโบราณคดีที่หลากหลายอันส่งผลกระทบทั้งทางบวกและทางลบ การแบ่งแยกระหว่างคน นอกและคนท้องถิ่นเป็นกระแสสำคัญในวาทกรรมสมัยหลังสมัยใหม่นิยม นักโบราณคดีตระหนักถึง บทบาททางจริยธรรมและการเมืองเมื่อโบราณคดีถูกใช้สำหรับการผลิตความรู้ การพัฒนาเศรษฐกิจ และเป้าหมายของนโยบายสาธารณะอื่นๆ ในระดับท้องถิ่น ประเทศ และนานาชาติ หลายปีที่ผ่านมามี 
ผลกระทบในประเด็นจริยธรรมที่เกี่ยวข้องกับการทำงานร่วมกับชุมชนที่หลากหลาย หรือกลุ่มชาติพันธุ์ ต่างๆ กลายเป็นสิ่งที่สำคัญสำหรับนักโบราณคดีทั่วโลก กรณีของประเทศไทย นักโบราณคดีส่วนใหญ่ ไม่ได้ให้ความสำคัญกับประเด็นเหล่านี้ แม้ว่าจะมีกลุ่มชาติพันธุ์ที่เป็นชนกลุ่มน้อยจำนวนมากในประเทศ ไทย โดยเฉพาะบริเวณชายแดน ความท้าทายในปัจจุบันคือการเชื่อมโยงแนวคิดทฤษฎีและระเบียบวิธี ปฏิบัติทางโบราณคดี กับภูมิปัญญาท้องถิ่นของหลากหลายชุมชน แม้ว่าจะมีความแตกต่างไปจากโลก ทัศน์ทางวิทยาศาสตร์ บทความนี้พิจารณาสองประเด็นหลัก คือ 1) นักโบราณคดีต่อรองความ รับผิดชอบทางจริยธรรมในการทำงานกับชุมชนหลากหลายกลุ่มอย่างไร 2) นักโบราณคดีสามารถหลอม รวมความรู้ท้องถิ่นเข้ากับการทำงานปฏิบัติ้และการตีความทางโบราณคดีอย่างไร กรณีศึกษาจากพื้นที่ สูงในอำเภอปางมะผ้า จังหวัดแม่ฮ่องสอน ภาคตะวันตกเฉียงเหนือของประเทศไทย

Keywords: archaeological interpretation; contemporary archaeology; ethics; local knowledge; knowledge production; Pang Mapha | การตีความทางโบราณคดี, โบราณคดีร่วมสมัย, จริยธรรม, ภูมิ ปัญญาท้องถิ่น, การผลิตความรู้, ปางมะผ้า

\section{Introduction}

We live in a world in which science proclaims and is believed, while local wisdom is often discounted or ignored. In our work, we archaeologists have relied heavily on scientific approaches to research and interpretation. Yet local knowledge is an important knowledge base in its own right that can "inform" our research practices and interpretations of the past. The challenge is how to integrate professional theoretical methodology with the local knowledge from multiple communities even when these are forms of knowledge in a what we see as "non-scientific" world view.

In some cases, local knowledge provides specific information that aids archaeological research, such as the locations of archaeological sites (e.g., Bruchac 2014; Pikirayi 2016; Whitley 2007). The use of other types of local knowledge is not as straight forward, however, local "legends," or oral traditions, which can have many versions, are examples. Perhaps we should not ignore local oral traditions altogether, but instead use them as another source of guidance for the history of the area. This is the approach that I take in my research.

Relying on only one version of a legend from a single source might lead to the dissemination of information that is misleading. Instead, I suggest that listening to multiple independent sources of local stories may help us better understand the local history. Probability-wise, the more independent sources we have, the better able we will be to create an 'average' or 'representative' version of the local history.

In Thailand, where I work, there are many minority ethnic groups, especially near the borders with neighboring countries. There are areas where the greatest diversity of ethnic minorities is most concentrated. Yet archaeologists in these areas do not focus on these groups. Therefore, to be effective archaeologists in these regions we need to integrate our professional theoretical and methodological practice with the local wisdom from multiple local ethnic communities. 


\section{Definitions of Shan, Tai, and Thai}

"Shan" is a group of people who speaks Tai or Thai or Dai language and lives in northern Myanmar, Thailand and parts of southern China.

"Tai" or "Dai" means ethnic groups who speak a language of the Thai-Kadai family and live outside present-day Thailand. "Thai" means Tai ethnic groups who live in present-day Thailand.

\section{Integrative Approach}

An Integrative approach is increasingly applied in archaeology (e.g. Gamble et al. 2001; Roche 2017) as a way to provide a comprehensive overview of human past. In my research, an integrative approach in my research includes applying different theoretical concepts and methodological practices by drawing multi-disciplinary specialists from fields such as archaeology, anthropology, biology, earth science, physics, material science, history, linguistics, arts, and local knowledge.

Over three decades of practicing archaeology, as a western trained archaeologist, I have been interested in the study of relationships between humans and seasonal tropical environments. In my work, I applied the cultural historical and processual archaeological frameworks to establish the cultural chronology of an archaeologically unknown area and to explain past culture changes using various middle-range theories such as mobility organization (Shoocongdej 2000) and mortuary practice (Shoocongdej 2018). Methodologically, I have used the cross-cultural comparative studies as a comparable inquiry tool to develop middle-range theories and archaeological implications at the scales of the micro-meso and macro regional research. My research team has always been multidisciplinary as mentioned above. I think if we incorporate western theories and methodologies into our practice, this will put Southeast Asian prehistory/archaeology into the world archaeological context.

Over time, my worldview has changed due to my involvements with different communities in Thailand and Southeast Asia including local communities, the general public in Thailand, academic communities in different fields, government communities, private sector, corporate groups (Shoocongdej 2011a; Shoocongdej 2017a). As I have been working in an area with ethnic and cultural diversity in over two decades, I have gradually become sensitive to the tribal and local communities in my interpretation and archaeological practice, in my research for indigenous or local theories, as well as in heritage management. Consequently, I have used an interpretative archaeology approach (Hodder 2003; Hodder 2004) that involves self-reflexivity, the inclusion of tribal, local, and other relevant voices, and a decolonizing archaeology approach in my works (Shoocongdej 2011b; Shoocongdej 2017b, Shoocongdej 2019). The involvement of local voices in my research includes local knowledge from local history, legends, folklore, and animism ritual practice, which is incorporated into my fieldwork, interpretation, and heritage management activities. In other words, I have used an integrative approach that blends the western scientific inquiry and different theoretical approaches with the local knowledges.

Highland Pang Mapha is one of the terra incognita research areas and therefore the archaeological research is to establish a cultural chronology and study all of cultural components arising from the excavation, which requires different sets of theoretical and methodological applications, and the integration of local knowledge.

The challenge of Highland Pang Mapha, however, is that unlike North America, Australia or New Zealand, as the contemporary ethnic groups in Highland Pang Mapha have only relatively recently 
migrated to the area (Thai/Tai/Dai groups and other ethnic groups) and thus have no historical trajectories to the archaeological evidences (Hoontrakul 2006; Shoocongdej 2011a). Therefore, the challenge for applying an integrative approach in Highland Pang Mapha is how, and what can we select or use as a common ground of independent sources in our research?

My points regarding the challenge for integrating local knowledge into the archaeological research methods and interpretation are structured as follows 1) the historical background of Highland Pang Mapha; 2) the archaeological excavation at Long Long Rak cave; and 3) the integration of archaeology with animist rituals and the local knowledge arising from the oral histories, traditions, and creation myths of the Tai speaking people.

\section{Highland Pang Mapha Research Program}

Highland Pang Mapha is a small district in Mae Hong Son Province, Northwestern Thailand. This area is a borderland between Thailand and the Shan State in Myanmar. Significantly, Pang Mapha is distinctively diverse, both biologically and culturally. This district is populated by various ethnic groups who migrated to the area relatively recently over several decades, including the Shan (Tai), Karen, Lahu, Lisu, Hmong, and Lua. Over ten projects, between 1998 and the present, I have been working in Highland Pang Mapha running a multidisciplinary research program involving archaeology, physical anthropology, ethnoarchaeology, geoarchaeology, zooarchaeology, dendrochronology, molecular biology, history, museology, heritage management and local knowledge as part of a long-term research project in Pang Mapha district, Mae Hong Son Province. This research project addresses a series of general issues concerning the evolution of social organization and the nature of culture change in seasonal tropical environments. In this work, I was determined to search for "truth" in the archaeological knowledge.

Over 80 sites have been discovered during our archaeological surveys of the area, and the site occupations vary in age. Site types include burial, habitation, manufacturing, ceremonial, and rock painting. In 2002, the Ban Rai rockshelter was excavated, the Tham Lod rockshelter was excavated by 2003 and the Long Long Rak cave was excavated between 2013-2015. The three excavated sites are representative of sites in the region. Four distinct components were proposed for the local and regional sequences based on geological deposits and radiocarbon dating, earliest to latest as from Late Pleistocene (ca. 32,380-10,000 BP), Early Holocene (ca. 10,000-7,500 BP, Middle Pleistocene (7,500-2,500 BP), and Late Holocene (2,500-Present) (Gorman 1970; Grave 1997; Shoocongdej 2004, 2018; Wannasri 2004).

After finishing the excavations and preliminary analyses, Tham Lod and Ban Rai rockshelters have been managed as open-air site museums by the project. The objectives of management are to protect and preserve the archaeological sites and to develop areas to enable local communities, the general public, students, and scholars to learn to appreciate the rich heritages of Highland Pang Mapha. Since then we have worked closely with the local communities by integrating their local knowledge in my archaeological practice both before and after my research (Shoocongdej 2011a) topics of how archaeologist incorporate local knowledge into their archaeological interpretation and management, using integrative approach from Long Long Rak cave in Tham Lod village, Highland Pang Mapha in Northwestern Thailand. 


\section{Log Coffin Culture}

For this paper, I focus on the Late Holocene period, particularly the "Log Coffin culture" which I will discuss in more detail below. The distinctive cultural characteristics of the highlanders of whom I refer to as the "Log Coffin Culture" date to between 2,200-1,100 BP. The Log Coffin Culture is generally found all over the mountainous regions of Western Thailand from Mae Hong Son to Chiang Mai, Tak and Kanchanaburi (Sangvichien 1986, Sørensen 1974) particularly in the Pang Mapha District of Mae Hong Son Province where large numbers of log coffins were discovered. Their burial traditions were distinctive from those of the Central and Northeastern regions of Thailand for both primary and secondary burials were found here in which the body would be placed with different patterns carved on the head ends. The coffins were properly laid out in caves or on rock shelters in the positions carefully selected near to mountaintops and on sharplysloping cliffs. (Shoocondej 2006).

It is important to note that local communities and the general public are interested in this particular period because it is closely related to local belief in "Phi Man" (a spirit of the Shan ethnic group) and the evidence is more tangible than in the other periods. At the same time, the local government has a policy to promote the cultural and archaeological heritages in this area as a tourist attraction.

\section{Long Long Rak Cave and Tham Lod Village}

In 2010, Long Long Rak Cave in Ban Tham Lod of the Pang Mapha District was discovered and involved a large collection of human skeletal remains, artifacts and ecofacts being unearthed for the first time. The excavation was carried out by the Highland Archaeology Project in Pang Mapha District of Mae Hong Son Province between 2013-2016. This new information will help to confirm the chronology of the Log Coffin Culture and identify cultural similarities and differences with contemporary prehistoric sites found in the lowlands, in order to understand social and cultural developments of the Northern prehistoric inhabitants.

Before presenting the archaeological evidence and interpretation, I would like to provide the contextual information regarding the local community currently resident within Tham Lod village, the majority of whom are of the Shan ethnic group. The Tham Lod village began to be settled around 1969, approximately 50 years ago. However, according to the oral history account of an elder, their ancestors lived in present-day Myanmar, and they moved back and forth across the Thai-Myanmar border. At present, Shan people make a living by practicing horticulture and through tourism activities at the Tham Lod cave (Hoontrakul 2006). The Tham Lod community practices Buddhism together with animism of their ancestor and natural spirits as well as Phi Man, the Shan spirit mentioned above that later became associated with the log coffin. Phi Man has the same appearance as normal people and does not hurt anyone.

Between 2013-16, we excavated the Long Long Rak cave by permission of the Tham Lod villagers along with formal permission from the Fine Arts Department, Ministry of Culture. Since 2017present, the analyses of the materials and data recovered from the site have been on going. Here, I will present a brief summary of research results, followed by a discussion of the negotiation process that took place with the villagers before excavation.

Long Long Rak Cave is a dry cave surrounded by mixed deciduous and bamboo forests, located on top of limestone cliffs about 735 meters above average sea level and about 300 meters from the course of Lang River. Long Long means coated coffins, Rak means lacquer of Gluta usitata (Wall.) rasin. The mouth of the cave opens up to a complex chamber approximately 15 meters down and is divided into three large chambers. The chambers are referred to as Chamber A, B and C during the 
excavation. Chamber A is further split into A1 and A2. There are 60 halves or about 30 full log coffins found in all three chambers. Only 44 of the lids/covers can be classified according to their styles while the remaining 16 are too corroded to identify. There are nine styles of log coffins heads identified (Sukliang 2014: 83-89)

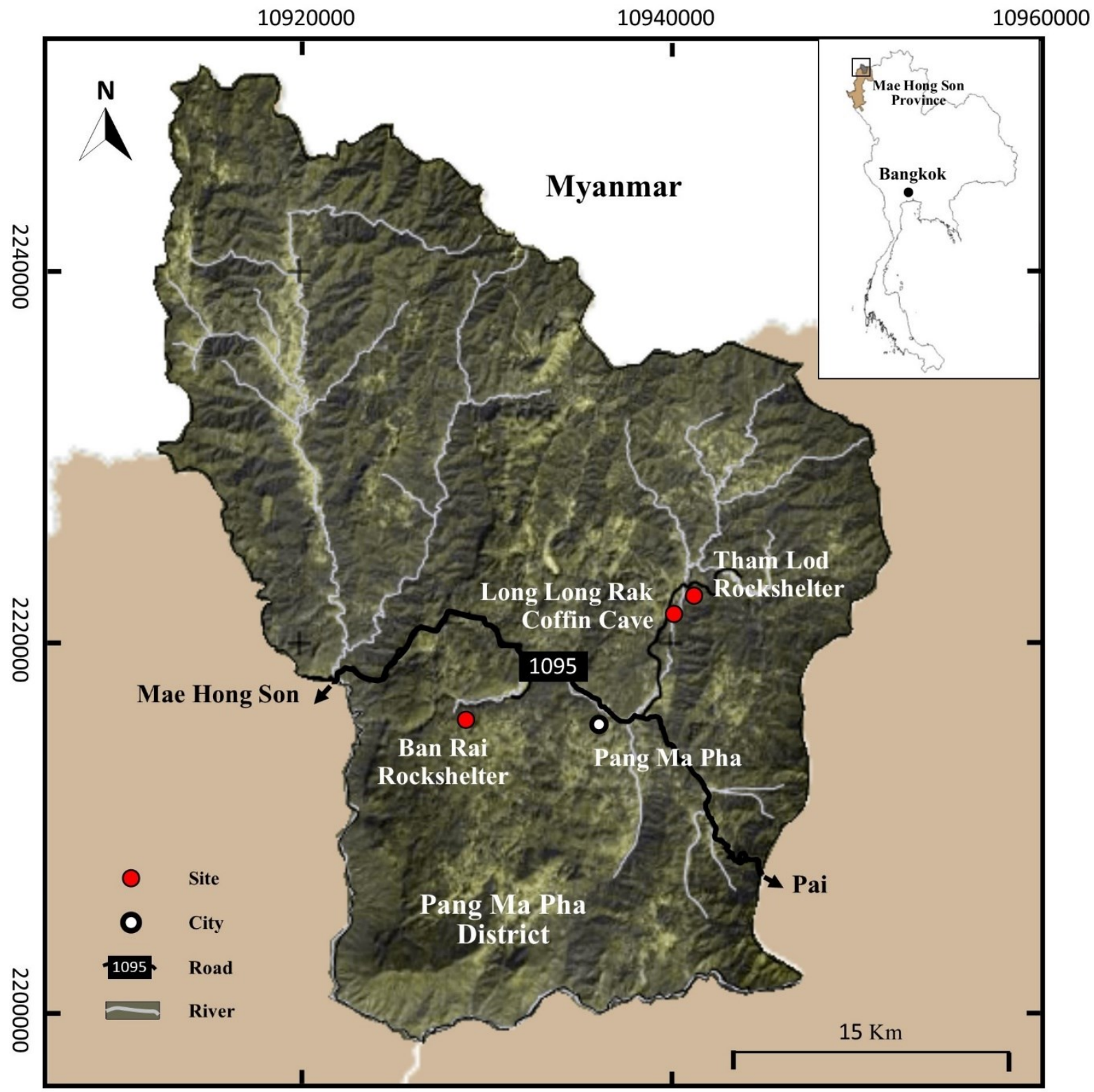

Fig. 1 Map show sites mentioned in the text. Source: Prehistoric Populations and Cultural Dynamics in Highland Pang Mapha Project 2018.

The project submitted 18 samples to Beta Analysis Inc., USA, including 10 wood samples from coffin lids and 5 samples of the resin that coats the coffin lids. An additional 3 wood samples from 3 coffin lids were submitted to the laboratory at Queen's University in Belfast, Northern Ireland, UK. (Pumjumnong and Shoocongdej 2015: 377-379; Shoocongdej, 2015: 373-376). The outcome of these analyses is that the site dates between $1960 \pm 30$ (Beta-398272) and 1636 \pm 44 cal. BP (UBA-27247). 
A preliminary study from tree-rings dating and wood species analysis revealed that all of the coffins were made of single teak logs split into halves. Only some of the coffins were made of two logs. Teak logs used in the making of the coffins were more than 100 years in age and may have grown under similar environmental conditions. The recovered potshards are clay-based round bottom pots, plates and bowls and typically found near the coffins. This indicates the coffins may have been filled with food offerings and the recovery of 80 glass beads suggests jewelry might have been worn by the deceased. Pottery, iron tools, bronze rings and glass beads are archaeological evidence which is normally found in log coffin culture. However, the excavations also revealed skeletons placed intentionally underneath the coffins but not arranged according to skeletal anatomy. There were also funeral offerings alongside the skeleton, which in addition to pottery, included pig jaws, wickerwork and weaving tools which have not yet been analyzed or classified according to archaeological artifacts. Additionally, the excavation revealed that some of the coffins had been placed on wooden posts, all of which are about one meter in length. The posts had been inserted under the head and leg parts of the coffins, and later analyses of these posts may help determine the time the coffins were buried.

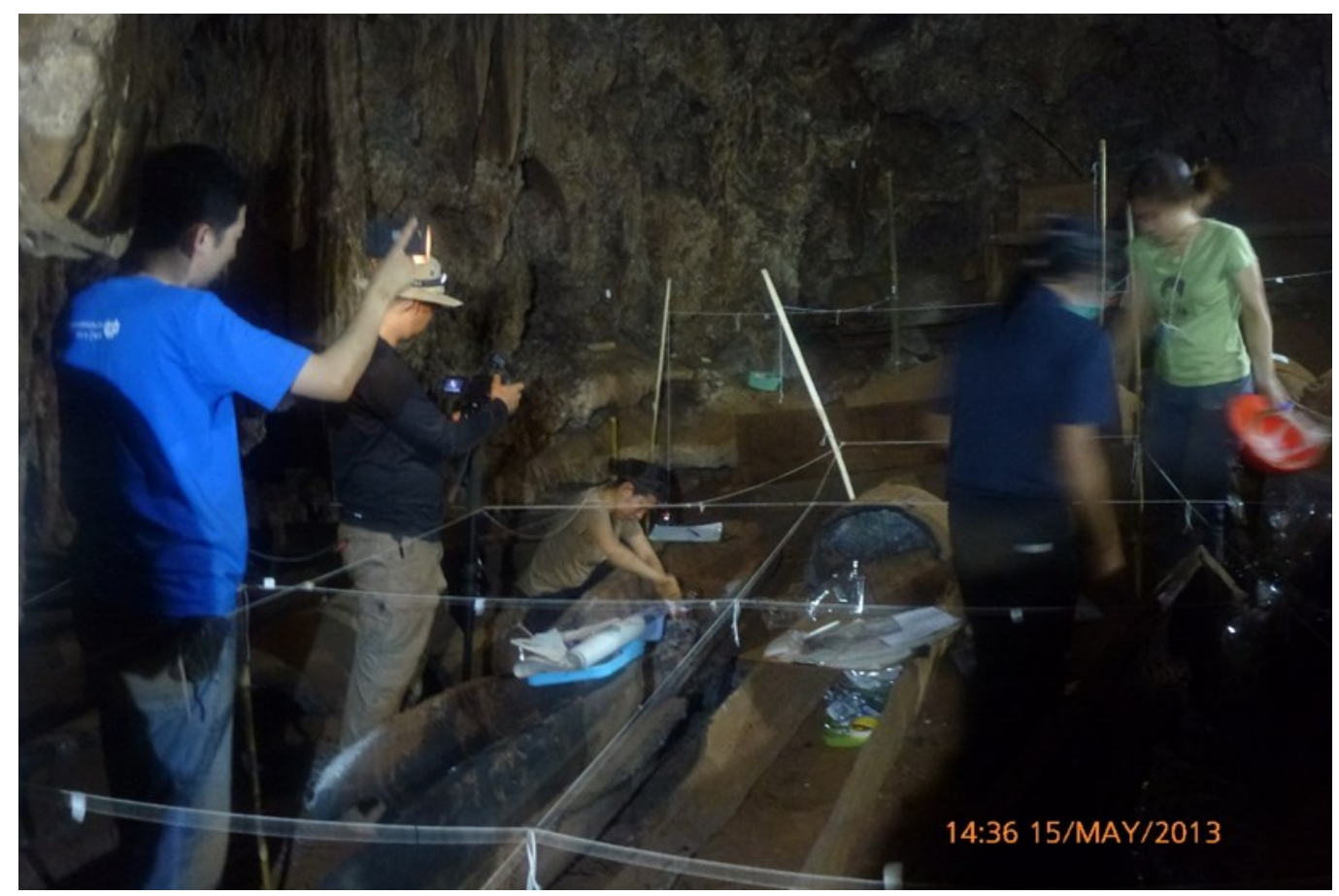

Fig. 2 Inside Chamber A1 at Long Long Rak Cave. Source: Prehistoric Populations and Cultural Dynamics in Highland Pang Mapha Project 2013.

It is interesting that the majority of the cultural objects found here are of ordinary and daily-use items. Only glass beads, bronze rings and iron bracelets were luxurious jewelries and could have been brought into the area from somewhere. The practice was different from contemporary sites within the same region or others that would intentionally make new potteries specifically for funeral use or the burial of luxurious items together with the deceased individuals (Higham and Thosarat 1998).

The minimum number of 154 individuals (MNI) were found, 116 from Chamber A1, 9 from A2 and 29 from B. The finding of the remains of both male and female adults along with a large number of children suggests that these people could be related to each other (Pureepatpong Kongkasuriyachai 
2016: 231-245). Dental samples were submitted for DNA analysis to identify relationships between the deceased individuals. The DNA results show two related populations of the Long Long Rak, the first group (1691 to 1537 cal BP) clusters with the Dai, Amis, and Kradai speakers from Thailand belonging to the Kradai and Austronesian language families and the second group (1570 to $1815 \mathrm{cal}$ BP) clusters with present day Austroasiatic speakers from Thailand and China (McColl et al. 2018: 92).

There are more DNA samples from the same cave and other caves in Highland Pang Mapha that still remain to be processed, along with other archaeological and ecological evidence.

\section{Integrating the Local knowledge in Archaeology Research}

This section presents archaeology incorporating local knowledge in both field practices, interpretation, and management.

\section{Local Knowledge and Archaeological Practice}

Here, I provide three specific examples on how I apply local knowledge for my survey, excavation, and interpretation.

\section{Oral Histories of the Local Ethnic Communities and Site discovery}

In order to address the above issues, the project conducted the ethnoarchaeological studies and oral histories of the local ethnic communities in highland Pang Mapha including Shan, Black and Red Lahu, Karen, and Lisu. The research focused on 1) the study of socio-cultural development of present ethnic highlanders and relationships with neighboring groups as a source of archaeological comparison; 2) a predictive model of settlement pattern for archaeological sites, and 3) the collaborative management of archaeological sites, which I will discuss hereafter (Hoontrakul, 2007; Shoocongdej 2007).

Based on the oral histories, the ethnic communities recently migrated from Myanmar, Chiang Mai and Mae Hong Son to Pang Mapha district. They often moved as a group of families or relatives. The Shan are the oldest ethnic groups who have settled down in highland Pang Mapha over two hundred years ago, while the rest are newcomers: the Karen came in 59 years ago, Lisu settled down around 57 years ago, while the Black and Red Lahu entered the area around 43 and 38 years ago respectively. Most of them moved from present-day Myanmar due to the internal conflicts and search for new agricultural lands (Hoontrakul 2007; Kantrasri 2007). The interview showed that the present ethnic communities have no historical connection to the archaeological sites we found in the area.

Indeed, I am aware of a validity of using modern oral histories to project the past. I am not using the method as a direct historical approach. Rather, I apply this as a conceptual tool to generate a logical reasoning for understanding the broader nature of human settlement which is either similar or different from archaeological site patterns as found in highland environments. However, the results of oral histories and ethnoarchaeology indirectly give us insight into the development of sitepredicted survey method and interpretation in the highland environments for our early years of research. The settlement patterns of ethnic groups in highland ecosystem consists of the Black and Red Lahu and Lisu, which can be further divided into two characteristics, namely the lower mountain ridge area and the steep limestone ridge or upper limestone karst. Both areas have different physical characteristics of geological formation and natural resources. The Shan and Karen 
often choose the river valley areas including flat plains, hilltops and high terraces along riverbanks. In general, the settlements are not only selected by the suitable environments but also their belief systems.

Searching for the sites in the evergreen forest in the highland environment is not an easy task. We first plotted the ethnic village settlement pattern and then overlaid with the previous archaeological sites appropriately. Later, we selected the survey areas and designed survey strategy according to the ethnic villages and we found over hundred archaeological sites which were more than we first surveyed in the year 2000 (Dilokwanitch 2002; Hoontrakul 2007; Shoocongdej 2007). This is a common approach found elsewhere such as Africa (Schmidt 2006).

Negotiating for Permission to Excavate with the Local Community

Our field practice, after we evaluated and selected the site to excavate, involved negotiating with the Tham Lod community for their permission before excavation process.

\section{Archeology and Animism Ritual}

Most of the tribal groups in the research area believe that the sites are the places of tribal spirits, and some communities will not allow archaeologists to work at their local sites because they are afraid that as a consequence, someone in the villages will die. Before the excavation, therefore, the research team organized three community forums to discuss the research with community leaders, village council and the Tham Lod people. These forums were about requesting permission to excavate at the site, but also included the importance of the Long Long Rak cave, and what needs to be researched before the community will manage what will be a new tourist attraction (Shoocongdej et al. 2013). I feel that meeting and creating a common understanding between researchers and the local community is of particular importance, and I strongly feel that any archeological work in the area must first obtain consensus from leaders and tribes. At the three meetings, the atmosphere was rather heated. Everyone asked many questions, particularly of myself as project leader until they received satisfactory answers. Finally, they voted to allow our excavation and research to go ahead and generate knowledge regarding log coffin culture for the community. But they requested that the appropriate rituals must be performed before the excavation in order to inform the sacred beings and spirits in the cave, which we agreed to. 


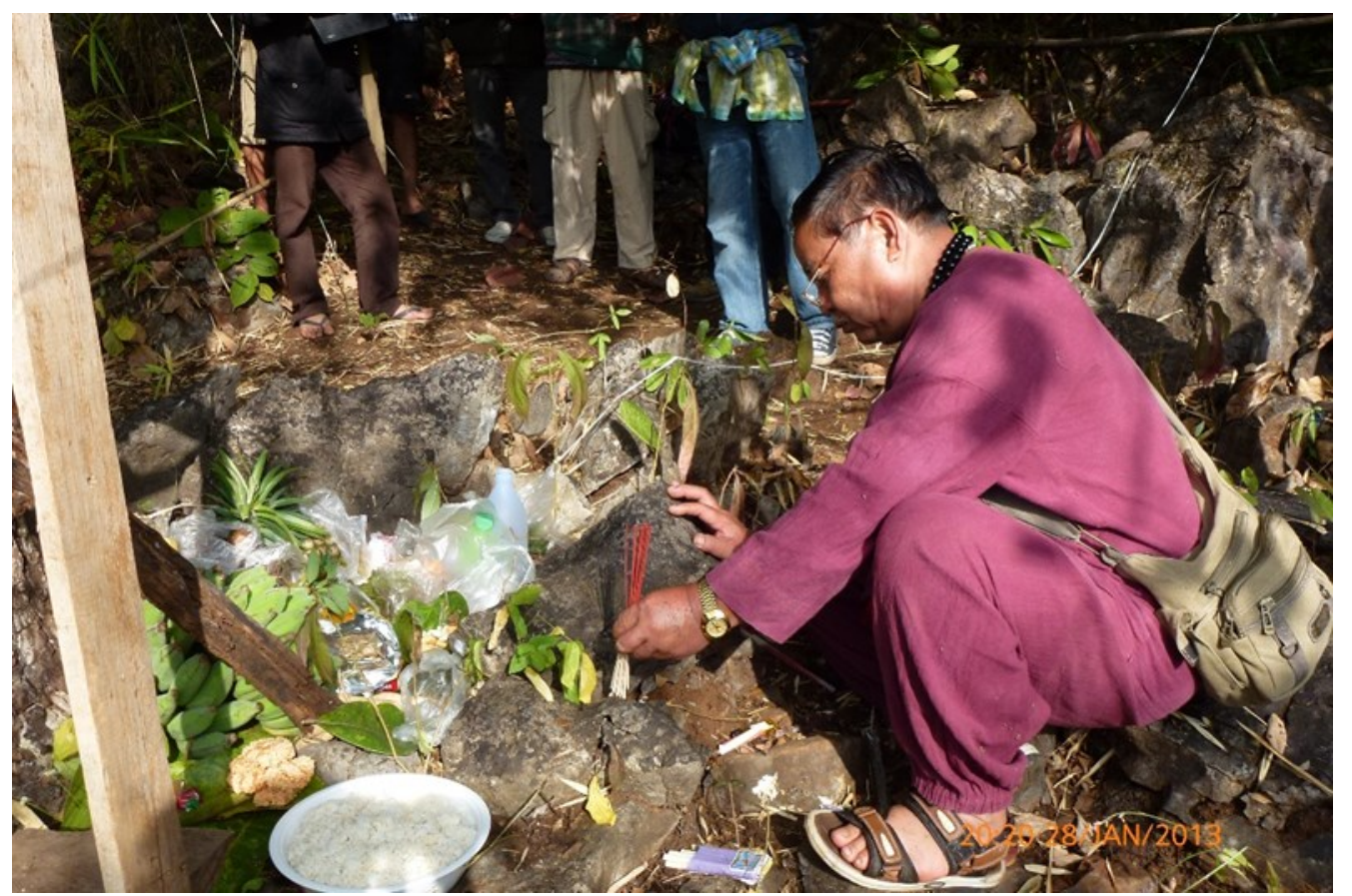

Fig. 3 Ritual worship before enter to the Long Long Rak Cave performed by the Shan Shaman. Source: Rasmi Shoocongdej 2013.

There are two forms of ritual worship: 1) lighting incense asking for forgiveness and for protection for the villagers and research team; and 2) paying respect to the sacred being and spirits of the coffins with a Shaman or Moh Mueang with small offerings such as chicken, liquor, soft drinks, fruit juice, foods, rice. After the worships, the Shaman asked the spirits and received a permission. The Shaman then walked through the cave with the research team. This is a common practice that is generally found in Southeast Asia. For example, at the Liang Bua archaeological site on the island of Flores, Indonesia, the local Manggarai believed that the excavation would disturb the "ghost' of the cave owners. Therefore, in 2001 Mike Morwood, the Australian archaeologist who was the principal investigator of the research project and the Manggarai local community made offerings of chicken and wine made from palm trees before the excavation commenced. (Morwood and van Oosterzee 2007). It can be seen that supernatural beliefs are common in Southeast Asian countries, and archaeologists need to follow the local belief as a way of showing our respect for the community we are working with.

\section{Local Knowledge and Archaeological Interpretation}

From the beginning of the Highland Pang Mapha research (1998) to the present project (2020), I have had several formal and informal meetings with the local communities, government and private agency asking the permissions to carry out my research in their villages and introducing the projects and research teams. My team has benefited from information from local traditions. First, we use local traditions to help interpret archaeological findings. Secondly, and perhaps more importantly, we integrate archaeology and physical anthropology with historical documents and myths to understand a broader perspective of the origin of what we found. 


\section{Local tradition and Archaeological Materials}

Two specific examples of how the local knowledge assisted our interpretation of archaeological materials. First, we found many thin black strings made of plants remains and coated with resin. While excavating the Long Long Rak cave, when we first discovered the fragments of strings, we didn't know what it was. We thought these were modern surface plants. But when we found a large lump in the pit, we reconsidered our primary interpretation. Later, we interviewed a Karen woman at the Muang Pam village in highland Pang Mapha and carried out a document research on the old photographs of ethnic groups in the area and neighboring countries. Surprisingly, we found out that these black strings were used for body decorations for males and females among the red Karen, Lua in Mae Hong Son province, Kayah in Myanmar (Na Nongkai 2016:378-380). Another example was the case of wooden loom found in the ground and inside the coffins. We analyzed the wooden loom made of teak tree as the grave goods and indicated the weaving technology. Once we interviewed the Karen female weaver at Muang Pam village, she told us that the looms are often made of teak or hardwood which would pass them from her mother and to herself. This information gave insight into our interpretation of grave goods relating to gender, specifically, female's belongings (Na Nongkai 2016: 389-391). Both cases show how we could not have interpreted the archaeological materials without the local knowledge.

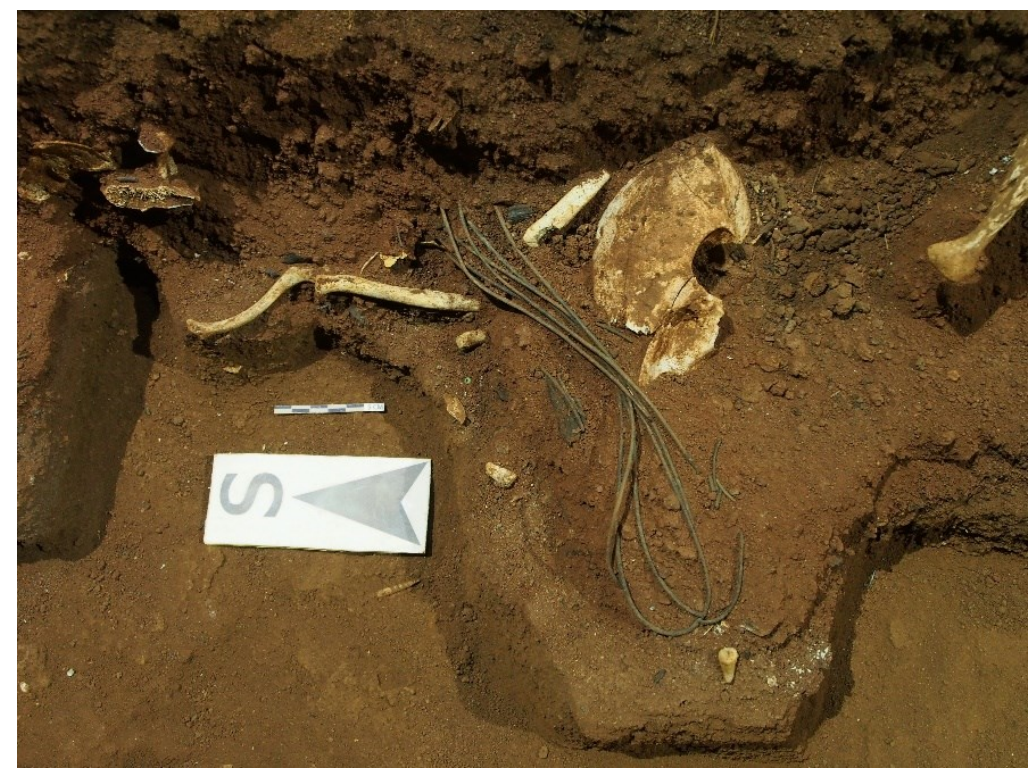

Fig. 4 A thin black string associated with skeletal remains. Source: Rasmi Shoocongdej et al. 2013. 


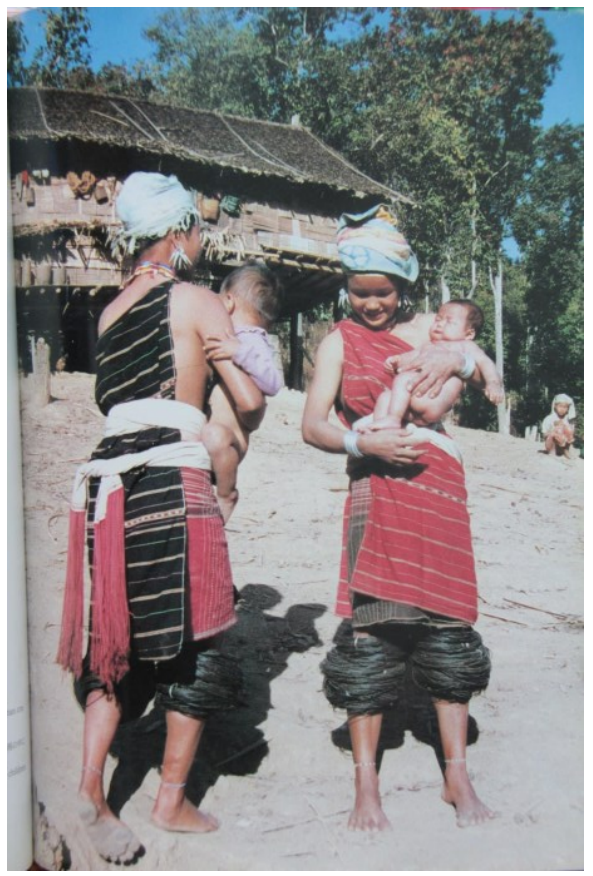

Fig. 5 A body decoration made of thin black string found in Karen ethnic group. Source: John Speies.

While obtaining help from locals, we also try to honor their traditions. For example, prior to our research in this area, an American archaeologist namely Chester Gorman called his excavated site containing the log coffin as "Spirit cave". But the locals named it "Phi Man". They believe that "Phi Man" is a very tall ghost who steals foods and crops from the village at night. If they make the "Phi Man" angry by disturbing the site, it might cause the death in the village. I have used the local Shan's term "Phi Man" representing the log coffin sites in research project "Tham Phi Man Long Long Rak" and it has been widely used by the general public (Shoocongdej 2018).

Integrating Archaeology and Physical Anthropology with Historical Documents and Myths

Physical evidence can be interpreted in many ways. In order to answer who were the ancestors of these people, we broaden our methodology to include historical archive, local histories, creation myth which provides additional framework to interpret biological and material evidence.

In addition, when we excavated the Long Long Rak cave, we found many intact human burial remnants of caskets and many other archaeological remains, including associated grave goods as previously discussed. We also were able to obtain precise dates for a fine-scale chronology of the Log Coffin Culture. I have conducted cross-cultural comparative studies of ethnographic data, ethnohistorical records and archaeological records from Myanmar, South China, Viet Nam, the Philippines and Malaysia with the archaeological assemblage from Long Long Rak cave and other Log Coffin Culture sites by using the diagnostic artifacts such as coffin head board style, lacquer, textile loom, glass beads and decorated teeth.

An analytical result based on physical anthropology revealed that bones and teeth found at Long Long Rak cave and other Log Coffin Culture sites contained features that were much more similar to the "present day Southeast Asian people" than the East Asian such as Chinese, Japanese or Korean (Nakbunlang 2003, Pureepatpong 2006, 2007). Recently published DNA results from Phi 
Man Long Long Rak (McColl et al. 2018) and other surveyed Log Coffin Culture sites in highland Pang Mapha (Kutanan et al. 2019) also provide similar results.

I, therefore, have to go back to the long-term local debates on "where the Thai/Tai came from" based on documented oral traditions and historical records along with linguistic distribution that Thai and Chinese scholars have been discussing over many decades. Because I don't want to fall into the trap of nationalism, I have been avoiding this particular issue. When the dating and DNA results from the Log Coffin Culture sites are more widely available to scholars, I think I should reexamine this debate again from my perspective. It is important to note that this contentious question is little known among the western archaeologists because most of the publications are either in Thai or Chinese. The sides in the debates include 1) Thai/Tai migrated from South China and are related to Zhang or Marn or Baiyue or Tai/Dai (e.g., Natsupa and Lohacharoon 2017; Saraya 2002; Satayawattana 2001; Sirindhorn Anthropological Center 2004; Vallibhodama and Wongtes 1993) and 2) the Thais are composed of various ethnic groups and lived in the area of present-day Thailand since 4,000 years ago based on the Neolithic (Wongtes 1984, 1987, 2005).

However, based on my literature review, I found some interesting evidences worth mentioning to promote further research. This part, I shall briefly discuss only the three cases related to 1) the "Zhuang", 2) "Marn" and 3) "Baiyue" or "Tai" and how these three are related to "Tai" or "Thai" in order to demonstrate how I integrate the local knowledge in my archaeological interpretation.

\section{"The Zhuang" and "Tai" or "Thai"?}

The well-known Thai anthropologists, Srisak Vallibhodama and Pranee Wongtes (1993), have suggested that the Zhuang and Thai/Tai are closely related. They used the material culture of rock art, kettle drum, the belief and ritual of rain calling and fog symbolism as their key evidence. The Zhung still use the bronze kettle drum for their ritual ceremonies which can relate to the bronze drum found at archaeological sites in South China and mainland Southeast Asia.

I follow their traces from archaeological evidence of the hanging coffins of the Bo people, an ethnic group once occupying the mountainous area on the border of Sichuan, Yunnan and Guizhou provinces in the northeast and southern of ancient China approximately 2300 years ago. The Bo people vanished from history during the end of the Ming Dynasty and the hanging coffin burials disappeared at the same time. Archaeologists studied the skulls obtained from the hanging coffin site of Matangba, south of Sichuan province (Hu and Xiao 1999), and the Washi and Longma archaeological sites in the northeast of Yunnan province and found that they are different from the present-day Chinese but contain a feature similar to the "current Zhuang" in Guangxi province (Ji et al. 2005). A comparative study of the two skulls from Yunnan province and other archaeological sites in Southeast Asia and East Asia, which is also related to the study of history of populations within the two regions, revealed that the skulls contain physical features that resembled to those of the Zhenpiyan people in Guangxi province of China of approximately 10,000 years ago. The discovery of the graves that contains tools and devices similar to the Hoabinhian and Bacsonian cultures of Vietnam suggests that the population in Southeast Asia and the people of Yunnan and the present Zhuang are all related. The researchers also surmised that they were also related to the prehistoric people that could have migrated northward from Vietnam (Ji et al. 2005: 9$11)$. 
Even though the numbers of skulls available for the comparative study of physical features were as small as three samples, I noticed that the Bo burial practice was inevitably similar to the Log Coffin Culture sites in Mae Hong Son province in terms of the chosen burial locations on the top of a mountain. A further comparative study could usefully examine the relationship of these people and their culture.

\section{"Marn"}

Eight decorated teeth were recovered from surveyed Log Coffin sites in Highland Pang Mapha may seem low in number, but most of the archaeological sites are almost completely destroyed with little archaeological evidence preserved, and most of this evidence is broken and incomplete. However, the significance of this evidence is the decoration of the teeth and the materials used. One to four holes were drilled into the outside surface of the upper front permanent teeth. Some of the teeth are coated in black with traces of a black stripe painted on them. The materials used in the decoration of the teeth are a combination of silver and gold (Chintakanon 2004).

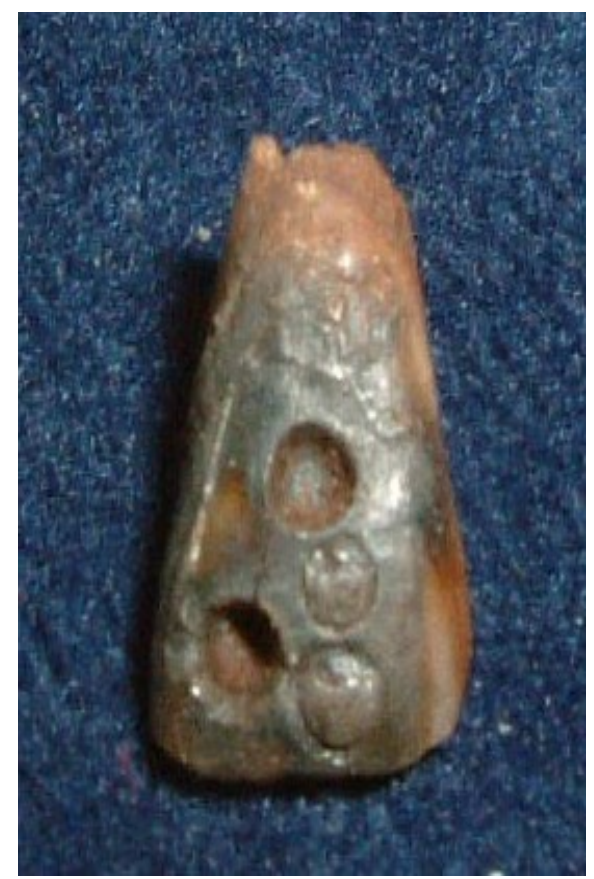

Fig. 5 A sample of a permanent upper incisor decorated tooth filling with mixed gold and silver and black coated. Source: Highland Archaeology in Pang Mapha Project 2006.

This tooth decoration raised two interesting issues worth discussing: the first is whether or not the people associated with the Log Coffin Culture was related to the "Marn," a tribe that lived in Yunnan province in southern China. The name "Marn" appeared in the written history of China which dated back to more than 2,000 years ago. The chronicle of Marn Su by Fanchua from the year 1867 (Fine Arts Department 1969) under the Tang Dynasty stated "The Marn had so many tribes and teeth decoration with materials such as gold was very popular among them and were therefore referred to as "The Golden Teeth" or "The Black Teeth" as they blackened their teeth with lacquer." It is presumed from the chronicle that that the "Marn" group could have been related to the "Tai." Based on the similarities 
between this account and the decorated teeth from the Log Coffin Culture sites, we cannot rule out the possibility of the relationship.

"Baiyue," "Thai" or "Tai?"

Thai anthropologist, Chontira Satayawattana (2001) has suggested that Baiyue and Tai are ethnically and culturally related. She based this on the following characteristics of material cultures: rice agriculture, bronze manufacture, and textile weaving patterns and techniques.

According to an ancient Chinese record from about 3,000 years ago, in the southern part of China encompassing the province of Yunnan to the coast, lived a group referred to by the Chinese as "Baiyue," which means hundred barbarians. Some Thai scholars have suggested that this group descended from the same family as the "Tai" or "Thai" (Wongtes 2005: 11618 ) or they were in some ways related, and that the "Baiyue" could have been the origin of many other ethnic groups including the "Tai" or "Thai"(Sattanawattana 2001).

\section{Relationships between the "Tai", the "Zhuang" the "Marn" and the "Baiyue"}

Even though the origin of the "Tai" has not been scientifically confirmed, many scholars have emphasized the possibility of the Tai being related to the "Marn" and "Baiyue" ethnic groups. Additionally, a historical record of the Zhuang during the end of the Qing Dynasty indicates that the Zhuang would gouge and decorate their teeth with gold and silver to show off their wealth, and preferably do this display on the upper front teeth rather than the lower teeth so as to make this display of wealth more obvious (Fine Arts Department 1969). The practice was also sexually dimorphic: men would decorate their left canine teeth while women would decorate their right canine teeth (Yu-Ru Yu and Mor Yun Zhwin 1999: 1819). The tradition of the Zhuang decorating their teeth with silver and gold of the Zhuang may have very ancient origins. Although the pattern and style may have been modified to reflect different social status and regional influences, the practice remained popular and worthy further study. This is because any future findings of decorated teeth in the Log Coffin Culture may be a key factor in unlocking the answer to substantial archaeological questions.

\section{"The Creation Myths of the Tai Speaking Peoples"}

Creation myths are another source for studying the distribution of Tai speaking people in Zhuang, Tai Lue from South China, Tai Yai (Shan) from Myanmar, Tai Yai, Tai Lue, Tai Khoen, Tai Yuan, Tai Isan from Thailand, Laos, Red Tai, Black Tai and White Tai from Vietnam, and Tai Ahom in the Brahmaputr valley of Assam from India (Nathalang 1996; Terwiel 1982). The creation myths represent Tai indigenous beliefs about the creation of the world and human beings and can be used to infer the relationships of Tai people by using the folklore method of content analysis to analyze the structure of the Tai creation myths. Siraporn Nathalang (1996: 71-78), an anthropologist, concluded that 1) all Tai groups have indigenous beliefs in world creators; 2) the creation myths imply social hierarchical societies, especially an elite class; 3 ) the content in the myths includes the origin of rice or rice agricultural practice; and 4) the creation myths are able to differentiate Tai from other ethnic groups. Hence, the creation myths reflect Tai identity. Moreover, the creation myths cluster around the Central Mekong river extending from south China through northern Thailand and northern Laos which Nathalang has suggested this could be an important junction of various of Tai peoples who stayed and interacted with one another. Though we cannot refer to the time depth as other above groups and archaeologists have not yet compared the archaeological evidence from the areas mentioned. It is believed that the Tai- 
speakers are relative newcomers in the regions they currently occupied between tenth and thirteenth century (Terwiel 1982). I think the creation myths can be another approach to assist archaeological research in the future.

\section{Local Knowledge and Archaeological Management}

At the end, when managing archaeological sites and materials, there are numeral issues which I classify as knowledge management and physical management.

In terms of knowledge management, we have included the local knowledge and oral histories of our narrative in the guidebook, exhibitions, publications, and community involvement processes. In addition, we have been working with the Tham Lod school on transmitting our research into school curriculum including research interpretation based on local knowledge on archaeological materials such as loom, black string, lacquerware.

As for a physical management of the site, we are aware of the animism belief on spirits of the burials in the cave which is respected by the local communities. Before managing the site, we consult with the shaman and local communities about the proper way to do it. Though, the project is still ongoing, we have planned to conserve the main burial areas and make a route linking each cave chamber so the visitors will not go out of the trail. We have also intended to make a small exhibition at the entrance of the cave explaining the important of the archaeological evidence and the relationship between each burial location as a part of family cemetery which is similar to the contemporary death ritual and belief in many ethnic communities.

Last but not least, during our field survey, excavation, and post-excavation visits, we always offer foods to the spirits of the Long Long Rak cave as way to pay respect to the local belief and place. I find, in my many years of excavation, it is beneficial to all parties to respect local tradition.

\section{Discussion and Conclusions}

This research indeed demonstrates the benefits of integration of multi-level information in archaeological fieldwork, interpretation, and management of the sites. Apart than scientific method, I use the local knowledge, oral history, ethnography, ethnohistory, ethnoarchaeology as my primary sources to assist my survey, pre-excavation process, and interpretation of archaeological material and social organization at the Long Long Rak cave. Once I have a result from DNA analysis, log coffin style comparative analysis and C14 dating, I used the grand-narrative of historical documents on the Tai to explain the regional picture of the cultural development in highland Pang Mapha as a part of cultural movement and interaction. I suggested the possibility that the log coffin culture might had a close cultural relationship with the culture in present-day south China. At this point, I have to admit that I have an advantage from my Thai background on the debates about the movement of Tai people in modern Thailand. As mentioned above, I have tried to analyze and examine my archaeological research scientifically before using these sources of information on my final interpretation.

In the current archaeological environment in Southeast Asia, I think both western and other foreign archaeologists are urging us to apply a self-reflexive method in archaeology research. Archaeologists should have dialogue with local communities and be aware of existing local knowledge that might usefully be related to their research topics. Theoretically and 
methodologically, middle-range theories can be developed from the multiple independent sources of local knowledge, and these theories can generate archaeological implications. In terms of archaeological practice, collaborative efforts should go beyond only fieldwork where the local archaeologists are the facilitators in the field, but rather include an interpretative process by seeking local knowledge and incorporating it into archaeological interpretation. The body of knowledge of local community members and scholars should not be ignored by non-local archaeologists as a nonscientific knowledge. For me, this seems to be a harmonious compromise, and it is a way to integrate science and humanity together. I think a history of the "other" from a far distant past or a more recent past is as important as your own history.

In terms of ethics and on practical level, I would like to point out that it is necessary and important to have a community involvement in our research process. Because they will protect the archaeological resource sustainably. On academic level, the ethic of how to use the sources for our interpretation and to in-cooperate the local knowledge are also important issues. I think we cannot simply use direct historical approach in our analysis and interpretation, we must cross-examination our information from different sources. For example, the loom and gender, I did not only use the interview data from the Karen community but also Lahu community as well as investigated the cross-cultural comparative studies from ethnographic and archaeological data from Hainan island, Viet Nam on the foot braced loom and external braced loom weaving techniques which widely distribute among populations who speak Daic, Austonesian, Austroasiatic, Tiberto-Burman in mainland and island Southeast Asia (Buckley 2017).

Beyond this paper, my experience can be applied to prehistoric archaeologists, especially, those who work in late Prehistoric archaeology, often ignore the fact that there were many states or complex societies already in existence for millennia in Asia, and can be contemporaneous with prehistoric periods in parts of Southeast Asia. Therefore, the research emphasis generally focuses on science, and it is easy to overlook the other independent sources of local knowledge from humanities. Here, two-way interaction and communication between local or native and foreign archaeologists is needed. This can be a fruitful collaborative endeavor in which the local archaeologists who know the current local debates can provide alternative interpretations of the past and contribute to the world archaeological community.

Finally, I believe that archaeology is long-term ethnography, and this gradually led me to focus on my personal position within the academic profession. During many decades of work, I have tried to reach a compromise between my professional standing as a scientist and the local, national and international demands, as a part of my responsibility to these different communities. Having conducted long-term research using the tools of reflexive and cross-cultural comparative approach as well as rigorous scientific methods has helped me develop a better understanding of the Log Coffin Culture. But an unexpected consequence is the discovery of my own identity as a "Thai". The mtDNA results from log coffin people at Long Long Rak cave and other survey sites were from a Daic speaking group. If I had not been persistent in carrying out my research in this area on this topic, I would not have been able to obtain these results and expand our knowledge about the sociocultural development of late prehistoric Southeast Asia.

To conclude, through the examples of our research practices involving the Log Coffin Culture of Highland Pang Mapha, I have tried to show how to integrate scientific-based archaeological knowledge and professional theoretical and methodological practice with local wisdom from multiple communities in both archaeological fieldwork and interpretation. I aim to continue to explore this approach further with my long-term regional research. 


\section{Acknowledgement}

The research would not have been possible without the supports of the Thailand Science and Innovation (TSRI) for the supports over many years. I am most grateful to the anonymous reviewers for their valuable comments. Thank you to Susan Hayes, Tristine Smart, and Anchada Charoenrook for their fruitful comments of the earlier version of this paper. Special thanks to the Tham Lod, Ban Rai, Muang Pam, and Jabo communities for their hospitality and friendships. Lastly, to all of my research teams for their hard works and supports.

\section{References}

Bruchac, M (2014) Decolonization in Archaeological Theory. In: C Smith (ed.) Encyclopedia of Global Archaeology. New York: Springer, 2069-2077.

Buckley, C (2017) Looms, Weaving and the Austronesian Expansion. In: A Acri, R Blench \& A Landmann (eds.) Spirits and Ships: Cultural Transfers in Early Monsoon Asia. Singapore: ISEAS-Yusof Ishak Institute, 273-324.

Chintakanon, K (2004) Dental Decoration at Pang Mapha during 2000 Years ago [in Thai]. Journal of Arts and Culture, 25(12): 44-45.

Dilokwanitch, S (2002) Final Report of Cave Survey and Data-Based Management in Mae Hong Son Province [in Thai]. Bangkok: Thailand Research Fund.

Fine Arts Department (1969) Marn Su: Archive of Marn of Fun Chua [in Thai]. Bangkok: Fine Arts Department.

Gamble, LH, Walker, PL and Russell, GS (2001) An Integrative Approach to Mortuary Analysis: Social and Symbolic Dimensions of Chumash Burial Practices. American Antiquity, 66(2): 185-212.

Gorman, CF (1970) Excavations at Spirit Cave, North Thailand. Asian Perspectives, 13: 79-107.

Grave, P (1997) The Ring-Ditch Burials of Northwestern Thailand: The Archaeology of Resistance. Bulletin of Indo-Pacific Prehistory Association, 3: 61-166.

Higham, C and Thosarat, R (1998) Prehistoric Thailand: From early settlement to Sukhothai. Bangkok: River Books.

Hodder, I (2003) Archeological Reflexivity and the "Local" Voice. Anthropological Quarterly, 76(1): 55-69.

Hodder, I (2004) Theory and Practice in Archaeology. London: Taylor \& Francis.

Hoontrakul, U (2006) New Anthropological Perspective Through Archaeologists' Lenses. In: R Shoocongdej (ed.) Dynamics of Socio-Culture and Environment in Highland Pang Mapha District, Mae Hong Son Province [in Thai]. Bangkok: Ruenkheaw Printing, 417-419.

Hoontrakul, U (2007) Final Report of Highland Archaeology in Pang Mapha, Mae Hong Son Province, Phase II, Volume 6 (Ethnoarchaeology) [in Thai]. Bangkok: Thailand Research Fund.

Hu, X and Xiao, H (1999) A Metric Study on Bo Ren Skulls. Chinese Journal of Anatomy 22: 357361.

Ji, X, Nakayama, M, Han, K, Liu, X, Liu, H and Kondo, O (2005) Unique biological affinity of the hanging coffin people in ancient China based on craniometry of two skulls from Yunnan province, Anthropological Science 113(3): 259-271. 
Kantrasri, S (2007) Final Report of Management in Pai-Pang Mapha-Khun Yuam, Mae Hong Son Province Volume 6 (Ethnographic Research) [in Thai]. Bangkok: Thailand Research Fund.

Kutanan, W, Kampuansai, J, Srikummool, M, Brunelli, A, Ghirotto, S, Arias, L, Macholdt, E, Hübner, A, Schröder, R and Stoneking, M (2019) Contrasting Paternal and Maternal Genetic Histories of Thai and Lao Populations. Molecular Biology and Evolution, 36(7): 1490-1506.

Mccoll, H, Racimo, F, Vinner, L, Demeter, F, Gakuhari, T, Moreno-Mayar, JV, Driem, GV, Wilken, UG, Seguin-Orlando, A, Castro, CDLF, Wasef, S, Shoocongdej, R, Souksavatdy, V, Sayavongkhamdy, T, Saidin, MM, Allentoft, ME, Sato, T, Malaspinas, A-S, Aghakhanian, FA, Korneliussen, T, Prohaska, A, Margaryan, A, Damgaard, PDB, Kaewsutthi, S, Lertrit, P, Nguyen, TMH, Hung, H-C, Tran, TM, Truong, HN, Nguyen, GH, Shahidan, S, Wiradnyana, K, Matsumae, H, Shigehara, N, Yoneda, M, Ishida, H, Masuyama, T, Yamada, Y, Tajima, A, Shibata, H, Toyoda, A, Hanihara, T, Nakagome, S, Deviese, T, Bacon, A-M, Duringer, P, Ponche, J-L, Shackelford, L, Patole-Edoumba, E, Nguyen, AT, Bellina-Pryce, B, Galipaud, J-C, Kinaston, R, Buckley, H, Pottier, C, Rasmussen, S, Higham, T, Foley, RA, Lahr, MM, Orlando, L, Sikora, M, Phipps, ME, Oota, H, Higham, C, Lambert, DM and Willerslev, E (2018) The prehistoric peopling of Southeast Asia. Science, 361(6397): 88-92.

Morwood, M and Van Oosterzee, P (2007) A New Human: The Startling Discovery and Strange Story of the "Hobbits" of Flores, Indonesia. New York: Smithsonian Books/Collins.

Na Nongkai, W (2016) Shaking Thread, Weaving: Daily life Handicraft. In: R Shoocongdej (ed.) $A$ Proceeding of Symposium on Interactions Between Prehistoric Populations and Environments in Highland Pang Mapha District, Mae Hong Son Province [in Thai]. Bangkok: Thailand Research Fund, 373-399.

Nakbunlang, S (2003) Overview Picture of Physical Anthropology, paper presented at A Proceeding of Symposium on Human, Culture, and Paleoenvironment in Highland Pang Mapha, 20-21 February, Bangkok.

Natsupa, C and Lohacharoon, U (eds.) (2017) Tai Ethnic in People Republic of China [in Thai]. Bangkok: Sangsan Printing.

Nathalang, S (1996) An Analysis of the Creation Myths of the Tai Speaking Peoples [in Thai]. Bangkok.

Pikirayi, I (2016) Archaeology, Local Knowledge, and Tradition: The Quest for Relevant Approaches to the Study and Use of the Past in Southern Africa. In: P Schmidt \& I Pikirayi (eds.) Community Archaeology and Heritage in Africa: Decolonizing Practice. London: Taylor \& Francis, 112-135.

Pumjumnong, N and Shoocongdej, R (2015) Radiocarbon of Log Coffin in Pang Mapha. In. R Shoocongdej (ed.) Progress Report of Interactions between Prehistoric Population and Environments in Highland Pang Mapha, Mae Hong Son Province, Volume 4 [in Thai]. Bangkok: Thailand Research Fund, 337-379.

Pureepatpong, N (2006) Recent Investigation of Early People (Late Pleistocene to Early Holocene) from Ban Rai and Tham Lod Rock Shelter Sites, Pang Mapha District, Mae Hong Son Province, Northwestern Thailand. In: E Bacus, I Glover \& V Pigott (eds.) Uncovering Southeast Asia's Past. Singapore: NUS Press, 38-45.

Pureepatpong, N (2007) Final Report of Highland Archaeology in Pang Mapha, Mae Hong Son Province, Phase II, Volume 3 (Physical Anthropology) [in Thai]. Bangkok: Thailand Research Fund. 
Pureepatpong Kongkasuriyachai, N (2016) New Jigsaw of Log Coffin People from Long Long Rak

Cave. In: R Shoocongdej (ed.) A Proceeding of Symposium on Interactions Between

Prehistoric Populations and Environments in Highland Pang Mapha District, Mae Hong

Son Province [in Thai]. Bangkok: Thailand Research Fund, 219-230.

Roche, A (2017) An Integrative Approach for an Integrated Exploitation of Natural Resources:

Villae and Karstic Environment Around Banassac (France) in the Roman Period. Journal of Ancient Studies, Special Volume 4: 188-206.

Sangvichien, S (1986) Prehistoric Archaeology in Thailand [in Thai]. Bangkok: Amarin Printing.

Saraya, T (2002) Becoming Tai: The Historical Basis of the Thai Nation. Bangkok: Asian Institute,

Chulalongkorn University.

Satayawattana, C (2001) In Search of History and Culture of Baiyue: An Anthropological Study [in Thai]. Bangkok: Thailand Research Fund.

Schmidt, PR (2006) Historical Archaeology in Africa: Representation, Social Memory, and Oral

Traditions. New York: AltaMira.

Shoocongdej, R (2000) Forager mobility organization in seasonal tropical environments of western

Thailand. World Archaeology, 32(1): 14-40.

Shoocongdej, R (2004) Highland Archaeology in Pang Mapha, Mae Hong Son Province [in Thai].

Nakhon Pathom: Silpakorn University Press.

Shoocongdej, R (2006) Late Pleistocene Activities at the Tham Lod Rockshelter in Highland Pang

Mapha, Mae Hong Son Province, Northwestern Thailand. In: E Bacus, I Glover \& V Pigott

(eds.) Uncovering Southeast Asia's Past. Singapore: NUS Press, 22-37.

Shoocongdej, R (2007) Final Report of Highland Archaeology in Pang Mapha, Mae Hong Son

Province, Phase II, Volume 2 (Archaeology) [in Thai]. Bangkok: Thailand Research Fund.

Shoocongdej, R (2011a) Public Archaeology in Thailand. In: K Okamura \& M A (eds.) Global

Public Archaeology. New York: Springer, 95-111.

Shoocongdej, R (2011b) Contemporary Archaeology as a Global Dialogue: Reflections from

Southeast Asia. In: LR Lozny (ed.) Comparative Archaeologies: A Sociological View of the

Science of the Past. New York: Springer, 707-730.

Shoocongdej, R (2015) ถ้ำผีแมนโลงลงรัก: ข้อมูลใหม่ของโบราณคดีสมัยก่อนประวัติศาสตร์ภาคเหนือ

[Long Long Rak Cave: New Data for Prehistoric Archaeology in Northern Thailand.

Veridian E-Journal, 8(2): 2572-2589.

Shoocongdej, R (2017a) The Use of Theory in Thai Archaeology. In: R Sujjapun (ed.) Theory and

Art Critiques from Thai Academic Perspectives [in Thai]. Bangkok: Med Sai Printing, 176235.

Shoocongdej, R (2017b) The History and Practice of Archaeology in Thailand. In: J Habu, PV Lape

\& JW Olsen (eds.) Handbook of East and Southeast Asian Archaeology. New York:

Springer, 97-110.

Shoocongdej, R (2018) Log Coffin Culture of Thailand in the Southeast Asian Context [in Thai].

Bangkok: Charansanitwongse Printing.

Shoocongdej, R (2019) Decolonizing Archaeology: A Case of Prehistoric "Hoabinhian" in

Thailand. In: Chatravanich, S, Apornsuwan, T, Pongpaichit, P \& Chaiprasat, S (eds.)

Thailand in The Senior Scholar's Thoughts Volume 2. [in Thai], Bangkok: Thailand

Research Fund, 92-123. 
Shoocongdej, R, Chomdee, N, Kosaiyakanont, R, and Laopirun, M (2013) Final Report of Archaeological Investigation and Heritage Management in Pai-Pang Mapha-Khum Yuam, Mae Hong Son Province, Phase III, Volume 2 (Archaeology). [in Thai]. Bangkok: Thailand Research Fund.

Sirindhorn Anthropological Center (2004) Being Thai/Being Tai [in Thai]. Bangkok: Sirindhorn Anthropological Center.

Sørensen, P (1974) Prehistoric Iron Implements from Thailand. Asian Perspectives, 16(2): 134-173.

Sukliang, S (2014) Coffin Fragments, Phi Man, Death Ritual in Highland: An Archaeological Perspective from Long Long Rak Cave, Pang Mapha District, Mae Hong Son Province. In: P Krajaejun (ed.) Ghost as the Evidence of the Living and the Dead [in Thai]. Pathum Thani: Thammasat University, 71-101.

Terwiel, BJ (1982) Ahom and the Study of Early Tai Society, paper presented at The Second ThaiEuropean Research Seminar, June 14-18, Saarbruecken, Federal Republic of Germany. Vallibhodama, S and Wongtes, P (1993) Zhuang: The Oldest Relatives of Tai [in Thai]. Bangkok: Silpakorn University.

Wannasri, S (2004) A Dendroarchaeological Study of Log Coffins: Bo Krai Cave and Ban Rai Rockshelter in Pang Mapha District, Mae Hong Son Province. MA Thesis, Mahidol University, Bangkok.

Whitley, PM (2007) Indigenous Knowledge and 21st Century Archaeological Practice: An Introduction. The SAA Archaeological Record, 7(2): 6-8.

Wongtes, S (1984) The Thai Does Not Come from Anywhere [in Thai]. Bangkok: Arts and Culture Printing.

Wongtes, S (1987) Where are the Thai [in Thai]. Bangkok: Arts and Culture Printing.

Wongtes, S (2005) Where Sukhothai Came From [in Thai]. Bangkok: Arts and Culture Printing. Yu-Ru Yu and Mor Yun Zhwin (1999) Trites de Passage of Zhuang, trans. M Charbwipas [in Thai]. Bangkok: Silapakorn. 